\title{
ROLE OF PARASURGICAL PROCEDURES IN THE MANAGEMENT OF SARPA VISHA
}

\author{
Anushree C G ${ }^{1}$,Nataraj $\mathbf{H ~ R}^{2}$,Prajwal $\mathbf{H ~ N}^{3}$, Deepa $\mathbf{P}^{4}$, Gazala Hussain ${ }^{5}$ \\ ${ }^{1,3,4} P G$ Scholar, \\ ${ }^{2,5}$ Associate Professor, Dept of AgadaTantra, Sri Dharmasthala Manjunatheshwara College of \\ Ayurveda \& Hospital,Hassan
}

Article DOI: https://doi.org/10.36713/epra7591 DOI No: 10.36713/epra7591

Corresponding Author :Anushree C G, PG Scholar, Dept of AgadaTantra,

Sri DharmasthalaManjunatheshwara College of Ayurveda \& Hospital, Hassan

\begin{abstract}
Agadatantra is one of the eight branches of Ayurveda. It is a branch in which treatment of various Sthavara( plant origin) and Jangama( animal origin)Visha( poisons) are described with signs and symptoms. A general principle for the treatment of poisoning is explained in AyurvedicSamhithas like Charaka, Sushruta, and Vagbhata. Snakebite is one among JangamaVisha( animal origin poison), its mortality in India is approximately 1300annually. The snakebite management protocol is elaborately prescribed by the World Health Organization (WHO). AcharyaCharaka has explained ChathurvimshathiUpakrama( $\sim 24$ treatment procedures) for the management of all types of poison including snake bite.Agnikarma( Cauterization), and Raktamokshana( $\sim$ Blood letting), are the only two Para surgical procedures among 24 treatment modalities. Para surgical procedures help to get rid-off localized poison immediately thus preventing the spread and further complications. This article is an extensive review mainly focussed on the role of Para surgical procedures in the management of SarpaVisha( $\sim$ Snakebite poison).

KEYWORDS: Agnikarma, Ayurveda,Chaturvimshatiupakrama,Parasurgicalprocedures, Raktamokshana,Snak ebite management.
\end{abstract}

\section{INTRODUCTION}

AgadaTantra is one of the eight branches of Ayurveda. Which deals with various types of poisons, their signs, and symptoms, diagnosis, and management ${ }^{1}$.Acharya Vaghbata explained general SarpaVishaChikitsa based on Dosha(Bioenergy center),Sthana (Site),Prakriti (Nature),Vega (Stage).

- In DarvikarasarpaDamsha( Bite of hooded snakes)-

Pana(Drink)ofSindhuvaaritaMoola(Vitexne gundo Linn), orGirikarnika(Clitoriaternatea Linn).
- In Mandala Sarpa Visha( Bite of Snakes with patches) -Equal quantity of Sugandha(Santalumalbum),Mridvika(Vitisvi nifera), Gajadantika with half quantity of SourasaPatra,Kapittha(Feronialimonia Linn),Bilwa(Aeglemarmelos),Dadima(Punic agranatam Linn),Kshoudra (Honey).

- In Rajimantha Sarpa Visha( Bite of Snakes with Stripes)-Katuka(Picrorhiza kurroa),Kushta(Saussurea lappa),Vyosa(Zingiberofficinale, Piper nigrum, Piper longum),Tagara(Valeriana wallichii DC) made into paste and 


\section{EPRA International Journal of Research and Development (IJRD)}

consumed mixed with honey,destroys the poison of snakes with stripes.

- Adravyaor Mani Prayoga-Dharana ofMarakata(Emerald), Vaidoorya(Cat's eye),Vajra(Diamond),Himavat(Acorusgram eneusSoland),Drona(Leucasaspera),Punarn ava(BoerhaaviaDiffusa),Mahadrona(Leucas cephalotes),Maanasi

- AgadaProyoga-

Himavatagada,Bilwadiagada,Sarvakarmika agada,Vajradiagada,Mritasanjivinigulika,A shtangaagada ${ }^{2}$

AcharyaCharaka has explained ChaturvimshatiUpakrama( 24 treatment procedure) as the general line of management for all types of Visha ${ }^{3}$, they include, Mantra ( Chanting hymns), Arishta bandana ( Tourniquet application), Uthkarthana( Incision), Nishpeedana( Squeezing), Chushana( sucking), Agni ( Cauterization), Parisheka( Sprinkling), Avagaha( Immersion bath), Rakthamoshana( Bloodletting), Vamana( Emesis), Virechana( Purgation), Upadhana( Applying the medicine over incised scalp), Hrdayavarana( protection of hridaya), Anjana( Collyrium), Nasya( Nasal instillation), Dhoopa( Fumigation), Leha( linctus), Aushadha( medicine), Prashamana( pacifying measure),

Prathisarana( rubbing), Prathivisha( antidote), Sanjastapanam( $\sim$ regaining consciousness), Lepa( oinments), Mrthasanjivani( revival). Among these, Agnikarma( Cauterization), and Raktamokshana( Bloodletting), are the onlyparasurgical procedures.

\section{AGNIKARMA}

The word Agni Karma is made up of the combination of two words - Agni and Karma (i.e. fire and procedure). In short, we can say it is a procedure done by Agni( fire) for treating a disease ${ }^{4}$.

AcharyaCharaka explained Agni Karma in the context of Visha which is located in Twak( skin)and Mamsa( muscle). It is carried out in all the Visha( poison) conditions except in the case of the predominance of Pitta. As this procedure aggravates Pitta Dosha, it is contraindicated in MandaliSarpaVisha and RaktaDhatugataVisha. Blood is the important media through which the poison spreads. It blows up the poison in the body just as hot air blows up the fire. ${ }^{5}$ The site of the bite is cauterized with the help of heated rods of gold, iron, etc. In certain cases; it is carried by a burning faggot. Fire converts anything into ash within seconds and poison is no exception to this. Hence this cauterization is indicated in cases of poisoning. ${ }^{6}$

AcharyaSushruta mentioned the Agnikarma( cauterization)as supreme in all the para surgical procedures. A separate chapter is dedicated to Agni karma in Sutra Sthana, where every aspect of cauterization is being explained, which denotes its importance in the treatment during those periods.Sushruta has referred Agni karma ( cauterization) in Agropaharaniya, as Upayantra $^{8}$ and Anushstra9. AcharyaSushruta has specified the materials which are to be used for Agni Karmafor different site of application ${ }^{10}$;

1.Twakdagdha-Pippali(Piperlongum),

Ajashakrit(Feces of the goat),Godanta(Teeth of the cow), Shara(Arrow), Shalaka(Probes).

2. Mamsadagdha - JambhavoshtaShalaklaand Other metals.

Vaghbatahas also explained the same procedure of Agnikarma which is explained by Charakaand Sushrutha. In AshtangaSamgraha,a detailed description of Agni Karma( cauterization) is found in the 40th chapter of Sutra Sthana.In AshtangaHridaya, a detailed description of Agni Karma ( cauterization) is described in the 30th chapter of Sutra Sthana.

\section{RAKTAMOKSHANA}

The word Raktamokshana is made up of the combination of two words, i.e. Rakta which means blood, and Mokshana which means to leave. Raktamokshana means to let out blood. Raktamokshana treatment is very effective to neutralise toxin. ${ }^{11}$

According to Charaka,it is conducted by scrapping,application of Shringa( Cow's horn) VataVikara, Jalouka( Leech therapy)-Pitta Vikara, Alaabu(Pitcher gourd)-KaphaVikara or Ghatika( Medium sized glass jar with one open end)-VataVikara.If the blood does not ooze out easily, then the area must be rubbed gently but briskly to facilitate the free flow of blood. This process of rubbing is known as 'Pragharshana( Rubbing)', it is carried out with the powder of Trikatu(Zingiberofficinale, Piper nigrum, Piper longum), Rajini(Curcuma longa),Panchalavana(Five varieties of salts), Gorochana, Vartaka ${ }^{12}$

According

to Sushrutha,Raktamokshana( Bloodletting) is usually carried out in the veins around the bite site, if the poison has spread to the distant areas, the veins in the forehead or the extremities should be punctured $^{13}$. Raktamokshana( Bloodletting)should not be attempted in children, old aged people, and pregnant women ${ }^{14}$ Hence the process of bloodletting is one of the important procedures to control the intensity of the poison in case of poisoning.

It should be quickly resorted to in the cases where the site of the bite is discolored, rigid, swollen, painfull $^{15}$ 


\section{EPRA International Journal of Research and Development (IJRD)

Vaghbata also explained the same procedure as mentioned in Charaka and Sushruta and also explained,vitiated blood more than one Prastha (134 pala=768grams) should not allowed to flow out,even in strong person,if excess blood is let out and pureblood starts flowing.It should be arrested immediately. Otherwise, it leads to complications like fainting, cardiac complications, etc., Hence the physician should make every attempt to arrest the flow of the pureblood through intense cold procedures like Pariseka( S Sprinkling), Lepa(Ointment), etc., as these measures initiate the process of blood clotting and this prevents the loss of pure blood ${ }^{16}$.Vitiated blood spreading and circulating in the body surely causes death ${ }^{17}$. Hence it should be removed as quickly as possible. It is highly beneficial in conditions where the poison has spread to distant parts of the body.

\section{MATERIALS AND METHODS}

The study being a literary review, the sources of data are collected from Brihatriyis(CharakaSamhita,SushruthaSamhita,Ashta ngaSangraha/Hridaya), contemperory text books, relevant journals, and websites.

\section{DISCUSSION}

Superiority of Agnikarma

Agni Karma( cauterization)is superior to Bheshaja ( Medicine), Shastra ( Instruments)\&Kshara karma ( Caustic therapy)as a disease burnt with Agni will never reoccur. Visha( Poison)which cannot be cured with any other Upakramas( Treatments), can be cured with Agni

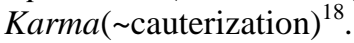

AgniKarma( cauterization)is a pain management procedure described in Ayurveda. From the ancient period, this procedure was performed in a different place with a different name. Nowadays modern science used cautery like instruments which are nothing but modified AgniKarma ( cauterization)only. This is a superior treatment to all other procedures. After AgniKarma ( cauterization)there is no chance of reoccurrence of Visha.( Poison).

\section{Superiority of Raktamokshana}

On the critical study of CharakaSamhita, it is recognized that the author has incorporated various aspects of Ratamokshana ( bloodletting therapy )as under.

$\square$ Types of Raktamokshana( Bloodletting)Sringa, ( Cow's horn) Jalouka( Leech therapy), Alaabu(Pitcher gourd), Ghatika( Medium sized glass jar with one open end).

$\square$ Method of application

$\square$ Places of Venesection to be done
Though CharakaSamhita is considered to primarily work on Kayachikitsa(General medicine), the matter related to other branches has also been dealt with comprehensively. However, the author is very much clear about the views and ideas while dealing with a patient other than his specialization. Hence, AcharyaCharaka has never crossed his jurisdiction at any point of time, while documenting the medical knowledge in his compendium. This is one attempt to describe all detailed information of Parasurgical procedures in snake bite poison in this article.

\section{CONCLUSION}

ChaturvimshathiUpakramas( 24 treatment procedures) are the first line of management in Sarpa $(\sim$ Snake) and all types of Visha ( Poison), among those Agni $\operatorname{Karma}(\sim$ cauterization) and Raktamokshana( bloodletting) are the Para surgical procedures mentioned in it,which helps to remove the localized poison by which it avoids systemic absorption of poison and prevents the further complication of poison,hence this Agni karma( cauterization)and

Raktamokshana( bloodletting) place a vital role in the primary management of the SarpaVisha( $\sim$ Snake bite poison).

\section{REFERENCE}

1. GautamBiswas, Review of Forensic medicine and toxicology, health science publisher New Delhi 3rd edition P-465.

2. Paradakara HSS,AstangaHridaya, uttarsthana, 36/18, ChaukhambaSurabhartiPrakashan, Reprint :2010. P-890.

3. Acharya YT CharakaSamhitha with Ayurveda Deepika Commentary of Chakrapanidatta, Reprint ed: Varanasi:Chaukamba Orientalia,2015; Chikitsasthana,chapter 23;P572.

4. Sharma A R, edited with 'susrutavimarsini' Hindi commentary.(1stEd.).Susrutasamhita, maharshisusruta.Sutra-stana;Agnikarmavidhiadhyaya: Chapter 12.verse no.1, 2 (dalhan). Varanasi: Chukhambhaprakashan, 2010; P-5.

5. Acharya YT CharakaSamhitha with Ayurveda Deepika Commentary of Chakrapanidatta, Reprinted:Varanasi:Chaukamba Orientalia,2015; Chikitsasthana,chapter 23;P574.

6. P.V.N.R.Prasad,IllustratedAgadatantra,Chaukha mba Sanskrit series office,Varanasi;Chapter 6;2019;P-91.

7. Sharma A R, edited with 'susrutavimarsini' Hindi commentary.(1stEd.).Susrutasamhita,maharshisu sruta. sutra-stana : Chapter 5.verse no.6.Varanasi : Chukhambhaprakashan, 2010 ;P-38.

8. Sharma A R, edited with 'susrutavimarsini' Hindi commentary.(1stEd.).Susrutasamhita,maharshisu 


\section{EPRA International Journal of Research and Development (IJRD)}

sruta.sutra-stana; Chapter7.verse no.15.Varanasi

: Chukhambhaprakashan, $2010 ; P-62$.

9. Sharma A R, edited with 'susrutavimarsini' Hindi commentary.(1stEd.).Susrutasamhita,maharshisu sruta. sutra-stana : Chapter 8.verse no.15.Varanasi : Chukhambhaprakashan, 2010 ; P-69.

10. Sharma A R, edited with 'susrutavimarsini' Hindi commentary.(1stEd.).Susrutasamhita,maharshisu sruta. sutra-stana: Chapter 12.verse no.4.Varanasi : Chukhambhaprakashan, 2010 ; P-85.

11. Dighe, D., Ratha, K. K., Panda, P., \& Rao, M. M. (2018). International Journal of Ayurveda. 6(2), $1-9$.

12. Acharya YT CharakaSamhitha with Ayurveda Deepika Commentary of Chakrapanidatta, Reprint ed: Varanasi:Chaukamba Orientalia,2015; Chikitsasthana, chapter 23;P576.

13. ShastriKA.,Sushruthasamhita,Ayurvedatatwasan deepika, hindi commentary, kalpa sthana,5/14,Chaukhamba Sanskrit sansthan Varanasi, edition-11,1997,P-40.

14. ShastriKA.,shruthasamhita,Ayurvedatatwasandee pika, hindi commentary,kalpa sthana,5/30Chaukhamba Sanskrit sansthan Varanasi, edition-11,1997,P-46.

15. ShastriKA,Sushruthasamhita,Ayurvedatatwasand eepika, hindi commentary,,kalpa sthana,5/36,Chaukhamba Sanskrit sansthan Varanasi, edition-11,1997,P-78.

16. Paradakara HSS ,AstangaHridaya, uttarsthana, 36/18, ChaukhambaSurabharti Prakashan,Reprint:2010,P-900.

17. Paradakara HSS, AstangaHridaya, uttarsthana, 36/18, ChaukhambaSurabharti Prakashan,Reprint:2010.P-901.

18. Sharma A R, edited with 'susrutavimarsini' Hindi commentary.(1stEd.).Susrutasamhita,maharshisu sruta. sutra-stana; Agnikarmavidhi-adhyaya: Chapter 12.verse no.3.Varanasi Chukhambhaprakashan, $2010 ;$ P-85. 